\title{
Revegetation Trials on a Saltgrass Meadow
}

\section{JIM R. LUDWIG AND WILLIAM J. McGINNIES}

Highlight: Saltgrass (Distichlis stricta (Torr.) Rydb.) meadows may be converted to productive pasture if the low-value saltgrass is removed and productive forage plants established. Field planting trials were conducted in 1975 and 1976 to determine the effects of nitrogen fertilizer, chemical soil amendments, mulch, and furrows on establishment of crested wheatgrass (Agropyron desertorum (Fisch. ex Link) Schult.), tall wheatgrass (A. elongatum (Host) Beauv.), Russian wildrye (Elymus junceus Fisch.), and smooth brome (Bromus inermis Leyss.). In 1975, alternate-furrow planting produced thinner stands than nonfurrowed planting, but in 1976, yields of the 1975 planting were similar from both treatments. Nitrogen fertilizer did not improve stand establishment or yield. All species became established, but tall wheatgrass appeared to be least able to withstand the droughty conditions encountered in late 1975 and all of 1976 . In the 1976 planting, a straw mulch increased seedling height and vigor but did not increase the number of seedlings or stand ratings. Because of its combined high seedling vigor and good drought tolerance, crested wheatgrass produced significantly better stands than did the other three species in the 1976 planting.

Saltgrass (Distichlis stricta (Torr.) Rydb.) meadows, found extensively on lowland sites throughout the western United States, are of little value for livestock production. They are more moist than adjacent upland sites and have high potential for forage production if palatable salt and alkali tolerant grasses can be established (Plummer et al. 1955). The unpalatable saltgrass is difficult to eradicate because of its persistent rhizomatous growth. Mechanical treatments are usually not successful, but saltgrass has been successfully eradicated by spraying with glyphosate (McGinnics 1974).

Saltgrass meadows located on Natrustoll (solonetz) soils are characterized by high salt levels in the $\mathrm{C}$ horizon, an impermeable B horizon, soil crusting, low fertility and extreme heterogeneity. These soil characteristics make establishment of improved forage species difficult (Ludwig 1976). Legal restrictions on well drilling and lack of other suitable water prevent reclamation of these soils by leaching with irrigation water

Authors are former graduate research assistant, Colorado State Univ., and range scientist. Agricultural Research Service, U.S. Department of Agriculture, respectively. The study involved cooperative investigations of the Agr. Res. Serv., U.S. Dep. Agr., Fort Collins, Colo., and the Colorado Agr. Exp. Sta., Fort Collins. Published with the approval of the Director of the Colorado Agr. Exp. Sta. as Scientific Series Paper No. 68

Manuscript received September 23, 1977
(McGinnies et al. 1976). Soil reclamation treatments on drylands, such as fertilization, water catching and storage, chemical or organic amendments and deep tillage, have increased seeding success on saline-sodic soils in other locations (Soiseth et al. 1974).

In a greenhouse study using Natrustoll soils from various horizons, biomass yields of both the above- and below-ground plant parts of tall wheatgrass were lower on the $C$ horizon and on a mixture of $\mathrm{A}, \mathrm{B}$, and $\mathrm{C}$ horizons than on $\mathrm{A}$ or $\mathrm{B}$ horizons (McGinnies and Ludwig 1977). It was concluded from this study that one should avoid plowing into the $C$ horizon because of its high salt level, but the A and B horizons should be mixed by plowing to facilitate water infiltration and increase availability of nutrients. It was also concluded that nitrogen fertilizer increased biomass and improved infiltration under greenhouse conditions. The objectives of the field research reported here were to extend the greenhouse experiment to a field environment, to find palatable grass species adapted to Natrustoll soils, to evaluate the effects of $\mathrm{N}$ and $\mathrm{Ca}$ on seedling establishment, and to develop methods for establishing these species on Natrustolls under semiarid climatic conditions.

\section{Description of Study Area}

Field studies were conducted on a saltgrass meadow located along Eastman Creek on the Central Plains Experimental Range, about 19 $\mathrm{km}$ north of Nunn, Weld County, Colorado. The mean annual precipitation is $31 \mathrm{~cm}$, of which $85 \%$ falls between May and September. Average minimum temperature is $9^{\circ} \mathrm{C}$ and the average maximum is $25^{\circ} \mathrm{C}$. The frost-free period averages 133 days per year. Soils within the saltgrass meadow were classified as Natrustolls (Solonetz), and are characterized by a loamy A horizon, a columnar clayey B horizon and a clayey, saline C horizon. Analysis of this soil is as follows:

\begin{tabular}{lrrr} 
& \multicolumn{3}{c}{ Horizon } \\
pH (of saturated soil paste) & \multicolumn{1}{c}{ A } & \multicolumn{1}{c}{ B } & \multicolumn{1}{c}{ C } \\
Conductivity (mmho/cm) & 5.9 & 8.3 & 8.8 \\
Calcium (meq/l) & 1.8 & 2.5 & 12.6 \\
Magnesium (meq/l) & 9.0 & 4.1 & 6.6 \\
Potassium (meq/l) & 1.7 & 3.3 & 3.2 \\
Sodium (meq/l) & 3.9 & 2.4 & 6.1 \\
Bicarbonate (meq/l) & 8.6 & 26.4 & 174.6 \\
Cloride (meq/l) & 12.0 & 12.0 & 11.0 \\
Sulfate (meq/l) & 1.4 & 2.8 & 22.9 \\
Nitrate (meq/l) & 1.5 & 12.5 & 133.0 \\
Sodium adsorption ratio & 0.6 & 0.8 & 0.1 \\
& 3.7 & 13.7 & 78.6
\end{tabular}


Existing dominant species are saltgrass, alkali sacaton (Sporobolus airoides (Torr.) Torr.), western wheatgrass (Agropyron smithii Rydb.), blue grama (Bouteloua gracilis (H.B.K.) Lag. ex Steud.), and threadleaf sedge (Carex filifolia Nutt.). A permanent water table underlies the area at depths varying from 1 to 4 meters.

\section{Field Plantings}

A previously plowed plot area was sprayed with glyphosate in the summer of 1974 to kill the saltgrass, plowed that fall, and then disked and hand-raked in the spring of 1975. Field plantings of tall wheatgrass (Agropyron elongatum (Host) Beauv.), crested wheatgrass ( $A$. desertorum (Fisch. ex Link) Schult.), smooth brome (Bromus inermis Leyss.), and Russian wildrye (Elymus junceus Fisch.) were made on April 21, 1975. These four species had shown promise in adjacent adaptability trials. Two seeding methods, level drilled and alternate furrow (alternating seeded rows in deep furrows and seeded rows on level beds between the furrows) (McGinnies 1972), and two levels of nitrogen, 0 and $112 \mathrm{~kg} \mathrm{~N} / \mathrm{ha}$ as ammonium nitrate, were used with each species in a randomized complete block design with four replications. The furrows were constructed $15 \mathrm{~cm}$ wide and $10 \mathrm{~cm}$ deep with a hand-furrower. Seven rows per plot, each $6 \mathrm{~m}$ in length and spaced $30 \mathrm{~cm}$ apart, of each species were drilled $1.8 \mathrm{~cm}$ deep with a cone-type seeder. The seeding rate was one live seed per $\mathrm{cm}$ of seeded row. Fertilizer was broadcast. Plots were hand-weeded through the 1975 growing season.

Seedling counts were made on June 11, July 24, and September 20, 1975, on 1.5-m segments in each of four rows of cach treatment, or a total of $6 \mathrm{~m}$ of row per plot. Soil moisture samples were obtained from level and furrow rows periodically during the growing season at depths of $2.5,5$, and $7.5 \mathrm{~cm}$; the soil was oven-dried and soil moisture as percentage of dry weight of soil was determined. On September 28, 1975, at the end of the first growing season, seedling vigor ratings and stand ratings were visually estimated on all plots. Seedling vigor ratings were made on a scale of 1 to 5 , with 1 representing low vigor and 5 representing high vigor. Stand ratings were on a scale from 1 to 10 , with 1 representing no plants in the rows and 10 representing a solid row of seedlings. On June 28, 1976, during the second growing season, stands were again rated and above-ground biomass was clipped from all plots and oven-dried.

\section{Field Plantings}

The study location used in the 1976 field plantings was in the same enclosure as that used for the 1975 plantings. On April 16, 1976, each of the same four species was drilled to a depth of $1.8 \mathrm{~cm}$ in each plot with a cone-type seeder into a row $37 \mathrm{~m}$ long and spaced $46 \mathrm{~cm}$ from the adjacent row. The rows were split into 6-m-long treatment segments. Soil treatments consisted of a control, $3,360 \mathrm{~kg} / \mathrm{ha}$ straw mulch, $112 \mathrm{~kg} \mathrm{~N} / \mathrm{ha}$ as ammonium nitrate, $112 \mathrm{~kg} \mathrm{~N} / \mathrm{ha}$ as calcium nitrate, $176 \mathrm{~kg} \mathrm{Ca} / \mathrm{ha}$ as calcium chloride and $307 \mathrm{~kg} \mathrm{Cl} / \mathrm{ha}$ as potassium chloride applied as split plots with six replications. The calcium chloride was used as a chemically equivalent $\mathrm{Ca}$ comparison against calcium nitrate, and the potassium chloride was used as a chemically equivalent chloride comparison against calcium chloride. The straw mulch was held in place with chicken wire and the chemical soil amendments were broadcast. An herbicide (2,4-D amine) was sprayed on the plots to control weeds.

Seedling counts were made on June 7, July 19, and September 15, 1976, on a 3-m segment of each row in all treatments. At the end of the growing season, on September 15, seedling height measurements, seedling vigor ratings, and stand ratings were made for all plots.

All data were evaluated by using conventional analysis of variance techniques. The Student-Newman-Keul multiple range test was used at the $1 \%$ confidence level to test all significant main treatment effects.

\section{Results and Discussion}

Extreme variability in establishment was observed on the plot area for both 1975 and 1976 seeding trials. This variability was noticeable not only among individual plots and replications, but within the plots and subplots themselves. Because of the extreme variations in thickness of $A$ horizon and depth to the $C$ horizon (McGinnies et al. 1976), plowing brought patches of the $\mathrm{C}$ horizon to the surface, which caused the locally thinner stands and reduced yields.

Precipitation for the month of May in 1975 exceeded and in 1976 equaled long-term average of $6 \mathrm{~cm}$. In both years, precipitation for the period June-July-August was $11 \mathrm{~cm}$ while the long-term average was $15 \mathrm{~cm}$; however, plant growing conditions during this 3 -month period were even poorer than one might expect from the $4-\mathrm{cm}$ precipitation deficit.

\section{Field Plantings}

The average number of seedlings in the level plots was significantly greater than in the altcrnate-furrow plots on all dates (Table 1). The alternate-furrow plots had a lower stand rating for 1975 than did the level plots. However, in 1976, the level plots did not differ significantly from the alternate-furrow

Table 1. Effect of species and method of seeding on number of seedlings per $30 \mathrm{~cm}$ of row at 51,94 , and 152 days after planting during the 1975 growing season, seedling vigor rating and stand rating measured during 1975 and stand rating and herbage biomass measured during 1976. (Seeded April 21 , 1975.)

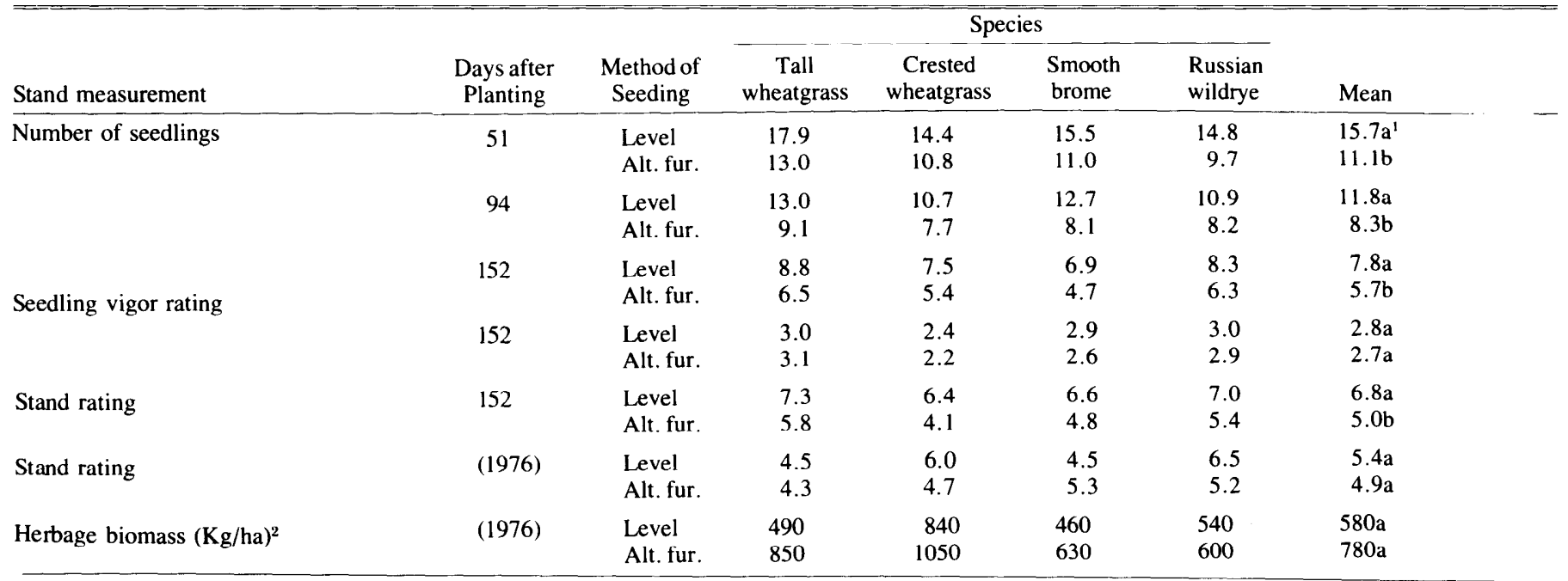

'Treatment means within each counting date and stand measurement with the same letter are not significantly different at the 0.01 level

¿ Oven dry. 
in stand rating and herbage biomass (Table 1). Addition of nitrogen fertilizer had no effect on average seedling numbers at any date (Table 2). Nitrogen fertilizer did not significantly increase seedling vigor, stand rating, or herbage biomass.

In a study on abandoned cropland of Oklahoma, Bryan and McMurphy (1968) reported that fertilization did not improve the stand establishment of certain range grasses but did increase forage yield in the second year after planting. Nitrogen fertilizer did not produce any increase in herbage biomass in our study, possibly because of the dry growing season in 1976. As the growing season progressed, numbers of seedlings per $30 \mathrm{~cm}$ of row declined for all species.

Species results were less consistent. In 1975, Russian wildrye had the highest stand rating and crested wheatgrass produced the greatest herbage biomass, but these differences were not statistically significant. No significant difference in stand rating or herbage biomass in 1976 resulted from the addition of nitrogen (Table 2).

Soil moisture data were evaluated after precipitation events that exceeded $1.7 \mathrm{~cm}$ to determine the ability of furrows to increase soil moisture. Only four precipitation events had sample data immediately before and after the events. The average soil moisture percentage for these four major precipitation events were as follows:

$\begin{array}{lll} & \begin{array}{l}\text { Furrow } \\ \text { bottom }\end{array} & \begin{array}{l}\text { Level } \\ \text { Before }\end{array} \\ 12.2 & 11.3 \\ \text { After } & 16.3 & 15.1\end{array}$

These determinations indicated no trend toward increased soil moisture retention in furrows.

Any beneficial effect of moisture accumulation in the furrows was offset by soil that washed into the furrows and covered the seed too deeply for satisfactory emergence. Seedling counts in furrows were significantly lower than those on the intervening beds. McGinnies (1972) used the alternate-furrow system for control of wind erosion., and reported that planting in furrows resulted in poorer stands on upland sites. Results from the 1975 planting on the saltgrass meadow were similar to the earlier results on the upland sites.

Plummer et al. (1955) suggested that tall wheatgrass was a most desirable species to plant under saline conditions. When compared to the other species we planted in 1975, it produced similar seedling numbers, seedling vigor, and stand ratings. However, during the 1976 growing season, tall wheatgrass appeared to be dying out in what we had previously thought to be well-established stands. Although tall wheatgrass is salt tolerant (McGinnies and Ludwig 1977), it apparently is not as drought tolerant as the other three grasses. The roots apparently were unable to reach permanently moist soil in 1975 and thus were not able to survive the drought in 1976. However, the stands of crested wheatgrass and Russian wildrye persisted well in spite of below-average precipitation.

\section{Field Plantings}

The addition of calcium, nitrogen, and mulch have been reported to improve seeded stands on solonetz soils (Toogood and Cairns 1973; Soiseth et al. 1974). In our 1976 field plantings, neither chemical soil amendments nor mulch had any significant effect on numbers of seedlings except that calcium chloride reduced seedling numbers at 51 days after planting (Table 3). The number of seedlings of crested wheatgrass was signiticantly greater than the number of the other three species on the last two counting dates (Table 4).

Seedling vigor ratings and heights were significantly better on the straw mulch treatment than on all other treatments (Table 3). Height and vigor of seedlings with the chemical amendments did not differ significantly and were no better than

Table 2. Effect of species and fertilized treatments on number of seedlings per $30 \mathrm{~cm}$ of row at 51,94 , and 152 days after planting during the 1975 growing season; seedling vigor rating and stand rating measured during 1975; and stand rating and herbage biomass measured during 1976. (Seeded April 21, 1975.)

\begin{tabular}{|c|c|c|c|c|c|c|c|}
\hline \multirow[b]{2}{*}{ Stand measurement } & \multirow[b]{2}{*}{$\begin{array}{c}\text { Days after } \\
\text { planting }\end{array}$} & \multirow{2}{*}{$\begin{array}{l}\text { Fertilizer } \\
\text { treatment } \\
(\mathrm{KgN} / \mathrm{ha})\end{array}$} & \multicolumn{4}{|c|}{ Species } & \multirow[b]{2}{*}{ Mean } \\
\hline & & & $\begin{array}{c}\text { Tall } \\
\text { wheatgrass }\end{array}$ & $\begin{array}{c}\text { Crested } \\
\text { wheatgrass }\end{array}$ & $\begin{array}{c}\text { Smooth } \\
\text { brome }\end{array}$ & $\begin{array}{l}\text { Russian } \\
\text { wildrye }\end{array}$ & \\
\hline \multirow[t]{3}{*}{ Number of seedlings } & 51 & $\begin{array}{c}0 \\
112 \\
\text { Mean }\end{array}$ & $\begin{array}{l}15.9 \\
15.1 \\
15.5 a\end{array}$ & $\begin{array}{l}12.0 \\
13.3 \\
12.7 b\end{array}$ & $\begin{array}{l}13.3 \\
13.2 \\
13.3 b\end{array}$ & $\begin{array}{l}12.9 \\
11.6 \\
12.2 \mathrm{~b}\end{array}$ & $\begin{array}{l}13.5 \mathrm{a}^{1} \\
13.3 \mathrm{a}\end{array}$ \\
\hline & 94 & $\begin{array}{c}0 \\
112 \\
\text { Mean }\end{array}$ & $\begin{array}{l}11.4 \\
10.8 \\
11.1 \mathrm{a}\end{array}$ & $\begin{array}{l}9.0 \\
9.4 \\
9.2 \mathrm{~b}\end{array}$ & $\begin{array}{c}11.0 \\
9.8 \\
10.4 \mathrm{ab}\end{array}$ & $\begin{array}{l}9.5 \\
9.7 \\
9.6 \mathrm{ab}\end{array}$ & $\begin{array}{r}10.2 \mathrm{a} \\
9.9 \mathrm{a}\end{array}$ \\
\hline & 152 & $\begin{array}{c}0 \\
112 \\
\text { Mean }\end{array}$ & $\begin{array}{l}7.7 \\
7.6 \\
7.7 \mathrm{a}\end{array}$ & $\begin{array}{l}6.6 \\
6.2 \\
6.4 a b\end{array}$ & $\begin{array}{l}6.7 \\
4.9 \\
5.8 b\end{array}$ & $\begin{array}{l}7.3 \\
7.3 \\
7.3 \mathrm{ab}\end{array}$ & $\begin{array}{l}7.1 \mathrm{a} \\
6.5 \mathrm{a}\end{array}$ \\
\hline Seedling vigor rating & 152 & $\begin{array}{c}0 \\
112 \\
\text { Mean }\end{array}$ & $\begin{array}{l}3.4 \\
2.8 \\
3.1 \mathrm{a}\end{array}$ & $\begin{array}{l}2.3 \\
2.2 \\
2.3 \mathrm{a}\end{array}$ & $\begin{array}{l}3.3 \\
2.2 \\
2.8 \mathrm{a}\end{array}$ & $\begin{array}{l}3.1 \\
2.8 \\
3.0 \mathrm{a}\end{array}$ & $\begin{array}{l}3.0 \mathrm{a} \\
2.5 \mathrm{a}\end{array}$ \\
\hline Stand rating & 152 & $\begin{array}{c}0 \\
112 \\
\text { Mean }\end{array}$ & $\begin{array}{l}6.8 \\
6.3 \\
6.6 a\end{array}$ & $\begin{array}{l}5.4 \\
5.1 \\
5.3 \mathrm{a}\end{array}$ & $\begin{array}{l}6.4 \\
5.0 \\
5.7 \mathrm{a}\end{array}$ & $\begin{array}{l}6.4 \\
5.9 \\
6.2 \mathrm{a}\end{array}$ & $\begin{array}{l}6.3 a \\
5.6 a\end{array}$ \\
\hline Stand rating & (1976) & $\begin{array}{c}0 \\
112 \\
\text { Mean }\end{array}$ & $\begin{array}{l}5.2 \\
3.6 \\
4.4 \mathrm{a}\end{array}$ & $\begin{array}{l}5.1 \\
5.6 \\
5.4 \mathrm{a}\end{array}$ & $\begin{array}{l}5.6 \\
4.1 \\
4.9 \mathrm{a}\end{array}$ & $\begin{array}{l}5.9 \\
5.8 \\
5.9 \mathrm{a}\end{array}$ & $\begin{array}{l}5.5 \mathrm{a} \\
4.8 \mathrm{a}\end{array}$ \\
\hline Herbage biomass $(\mathrm{kg} / \mathrm{ha})^{2}$ & (1976) & $\begin{array}{c}0 \\
112 \\
\text { Mean }\end{array}$ & $\begin{array}{l}860 \\
480 \\
670 a\end{array}$ & $\begin{array}{c}840 \\
1050 \\
950 \mathrm{a}\end{array}$ & $\begin{array}{l}650 \\
440 \\
550 a\end{array}$ & $\begin{array}{l}620 \\
530 \\
580 a\end{array}$ & $\begin{array}{l}740 \mathrm{a} \\
620 \mathrm{a}\end{array}$ \\
\hline
\end{tabular}

\footnotetext{
'Species and fertilizer means within each counting date and stand measurement associated with the same letter and not significantly different at the 0.01 level.
}

Overi dry. 
Table 3. Average number of seedlings for four grass species per $30 \mathrm{~cm}$ of row at 51,94, and 152 days after an April 1976 planting as affected by soil amendments. Average seedling vigor rating, seedling height, and stand rating were measured at the end of the growing season.

\begin{tabular}{|c|c|c|c|c|c|c|}
\hline \multirow{2}{*}{$\begin{array}{c}\text { Stand } \\
\text { measurement }\end{array}$} & \multirow{2}{*}{$\begin{array}{l}\text { Days after } \\
\text { planting }\end{array}$} & \multicolumn{5}{|c|}{ Soil amendment } \\
\hline & & Control & Mulch & $\mathrm{NH}_{4} \mathrm{NO}_{3}$ & $\mathrm{Ca}\left(\mathrm{NO}_{3}\right)_{2}$ & $\mathrm{CaCl} \mathrm{KCl}$ \\
\hline \multirow[t]{3}{*}{ Number of seedling } & igs 51 & $12.1 \mathrm{a}^{1}$ & $10.6 \mathrm{ab}$ & $10.2 \mathrm{ab}$ & $11.4 \mathrm{ab}$ & $9.3 \mathrm{~b} 11.8 \mathrm{a}$ \\
\hline & 94 & $6.9 \mathrm{a}$ & $6.7 \mathrm{a}$ & $5.6 \mathrm{a}$ & $6.4 \mathrm{a}$ & $5.8 \mathrm{a} \quad 7.2 \mathrm{a}$ \\
\hline & 152 & $4.8 \mathrm{a}$ & $4.3 \mathrm{a}$ & $3.9 \mathrm{a}$ & $4.6 \mathrm{a}$ & $4.2 \mathrm{a} \quad 5.2 \mathrm{a}$ \\
\hline Seedling vigor rating & ing 152 & $2.0 \mathrm{~b}$ & $3.0 \mathrm{a}$ & $2.1 \mathrm{~b}$ & $2.1 \mathrm{~b}$ & $1.9 \mathrm{~b} \quad 1.9 \mathrm{~b}$ \\
\hline Seedling height $(\mathrm{cm})$ & m) 152 & $7.9 \mathrm{~b}$ & $12.6 \mathrm{a}$ & $8.5 b$ & $9.2 \mathrm{~b}$ & $8.6 b \quad 8.6 b$ \\
\hline Stand rating & 152 & $3.8 \mathrm{a}$ & $4.3 \mathrm{a}$ & $3.0 \mathrm{a}$ & $3.8 \mathrm{a}$ & $3.4 \mathrm{a} \quad 3.6 \mathrm{a}$ \\
\hline
\end{tabular}

'Means within each countıng row with the same letter are not significantly different at the 0.01 level.

the control. Average stand rating was not significantly changed by any of the soil amendments. Crested wheatgrass had significantly taller and more vigorous seedlings than the other grasses, and had a higher stand rating than Russian wildrye and smooth brome (Table 4).

The 1976 growing season was below-average in seasonal precipitation, particularly early in the growing season. The combined precipitation for May and June, which were critical months for seedling establishment, was $3.8 \mathrm{~cm}$ below the 30 -year average of $11.8 \mathrm{~cm}$. There was a marked decrease in numbers of seedlings per $30 \mathrm{~cm}$ of row at the end of the growing season in 1976 as compared to numbers in 1975:

\begin{tabular}{lcc} 
& \multicolumn{2}{c}{ Seeding } \\
& $\mathbf{1 9 7 5}$ & $\mathbf{1 9 7 6}$ \\
Tall wheatgrass & 7.6 & 3.8 \\
Crested wheatgrass & 6.4 & 5.8 \\
Smooth brome & 5.8 & 4.1 \\
Russian wildrye & 7.3 & 4.2
\end{tabular}

The only soil amendment that effectively increased seedling height and vigor was straw mulch. Mulches are noted for their usefulness in conserving moisture by reducing evaporation and lowering soil temperature in arid areas (Springfield 1971). Because of its seedling vigor and seedling drought resistance, crested wheatgrass established more seedlings in 1976 than the other three species.

\section{Conclusions}

Crested wheatgrass appeared to be the best-adapted of the four species tried. Tall wheatgrass is commonly recommended for seeding saline soils, but it appeared to be more susceptible to drought damage than did the other three species. The lack of response to $\mathrm{N}$ fertilizer on this soil is surprising and should receive further study. Calcium alone or in combination with $\mathrm{N}$ at
Table 4. Average number of seedlings per $30 \mathrm{~cm}$ of row at 51 , 94 , and 152 days after 1976 planting and average seedling vigor rating, seedling height, and stand rating measured at the end of the growing season for four grass species. (Planted April 16, 1976.)

\begin{tabular}{lccccc}
\hline & & \multicolumn{4}{c}{ Species } \\
\cline { 3 - 6 } \multicolumn{1}{c}{ Stand } & $\begin{array}{c}\text { Days after } \\
\text { measurement }\end{array}$ & $\begin{array}{c}\text { Tall } \\
\text { planting }\end{array}$ & $\begin{array}{c}\text { Crested } \\
\text { wheatgrass wheatgrass }\end{array}$ & $\begin{array}{c}\text { Smooth } \\
\text { brome }\end{array}$ & $\begin{array}{c}\text { Russian } \\
\text { wildrye }\end{array}$ \\
\hline Number of seedlings & 51 & $10.3 \mathrm{a}^{1}$ & $12.1 \mathrm{a}$ & $10.2 \mathrm{a}$ & $11.0 \mathrm{a}$ \\
& 94 & $6.4 \mathrm{~b}$ & $8.2 \mathrm{a}$ & $5.5 \mathrm{~b}$ & $5.6 \mathrm{~b}$ \\
& 152 & $3.8 \mathrm{~b}$ & $5.8 \mathrm{a}$ & $4.1 \mathrm{~b}$ & $4.2 \mathrm{~b}$ \\
Seedling vigor rating & 152 & $1.9 \mathrm{~b}$ & $2.9 \mathrm{a}$ & $1.9 \mathrm{~b}$ & $1.9 \mathrm{~b}$ \\
Seedling height $(\mathrm{cm})$ & 152 & $8.3 \mathrm{~b}$ & $12.0 \mathrm{a}$ & $9.0 \mathrm{~b}$ & $7.7 \mathrm{~b}$ \\
Stand rating & 152 & $3.8 \mathrm{ab}$ & $5.0 \mathrm{a}$ & $3.2 \mathrm{~b}$ & $2.6 \mathrm{~b}$ \\
\hline
\end{tabular}

Species means within each counting date and stand measurement with the same letter are not significantly different at the 0.01 level.

the rates applied did not improve stand establishment or help rehabilitate sodic soils, although both $\mathrm{Ca}$ and $\mathrm{N}$ have been reported to be beneficial on similar soils. Furrowing produced poorer stands and did not significantly increase soil moisture at planting depth. No treatment used was completely satisfactory for the revegetation of the saline-sodic soils, although use of a heavy mulch was a significant help. Poor spots in seeded stands on salt meadow sites with Nutrustoll soils will probably be characteristic and unavoidable (Toogood and Cairns 1973), especially in years of below-average precipitation.

\section{Literature Cited}

Bryan, G. G., and W. E. McMurphy. 1968. Competition and fertilization as influepces on grass seedlings. J. Range Manage. 21:98-101.

Ludwig, J. R. 1976. Revegetation of a saltgrass meadow in northeastern Colorado. PhD Diss. Colorado State Univ., Fort Collins. 93 p.

McGinnies, W. J. 1972. An alternate-furrow system for seeding northern Colorado rangeland. J. Range Manage. 25:450-452.

McGinnies, W. J. 1974. Chemical eradication of desert saltgrass (Distichlis stricta (Torr.) Rydb.) for seedbed preparation. Res. Progress Rep. Western Soc. of Weed Sci. p. 26-27.

McGinnies, W. J., L. W. Osborn, and W. A. Berg. 1976. Plant-soil-microsite relationships on a saltgrass meadow. J. Range Manage. 29:395-400.

McGinnies, W. J., and J. R. Ludwig. 1977. Effects of Natrustoll (solonetz) soil horizons and nitrogen on growth of tall wheatgrass (Agropyron elongatum (Host) Beau.). Agron. J. 69:518-520.

Plummer, A. P., A. C. Hull, Jr., G. Stewart, and J. H. Robertson. 1955. Seeding rangelands in Utah, Nevada, southern Idaho and western Wyoming. U.S. Dep. Agr. Handb. 71.73 p.

Soiseth, R. J., J. R. Wight, and J. K. Aase. 1974. Improvement of pan spot (solonetzic) range sites by contour-furrowing. J. Range Manage. 27:107-1 10.

Springfield, H. W. 1971. Selection and limitations of mulching materials for stabilizing critical areas. Proc. Critical Area Stabilization Workshop. Rep. 7A, New Mexico Interagency Range Comm. p. 128-153.

Toogood, J. A., and R. R. Cairns. 1973. Solonetzic soils technology and management. Dep. of Ext., Univ. of Alberta, Edmonton. 92 p.

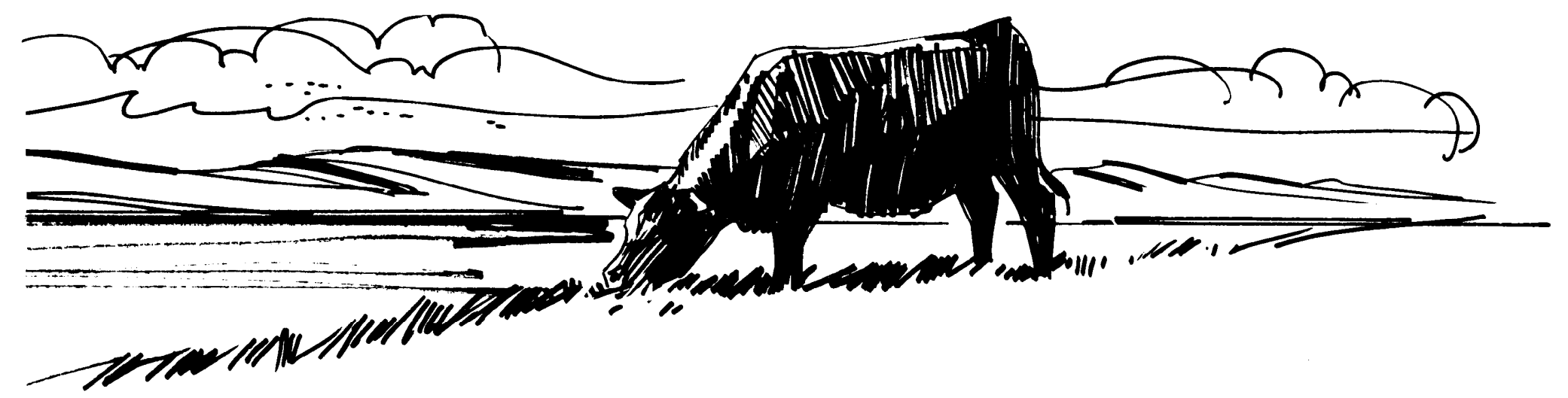

